\title{
Effect of Night Interruption with Mist and Shade Cooling Systems on Subsequent Growth and Flowering of Cymbidium 'Red Fire' and 'Yokihi'
}

\author{
Yoon Jin $\mathrm{Kim}^{1,2,3}$ and Ki Sun $\mathrm{Kim}^{2,3^{*}}$ \\ ${ }^{1}$ Department of Horticulture, Biotechnology and Landscape Architecture, Seoul Women's University, Seoul 139-774, Korea \\ ${ }^{2}$ Department of Horticultural Science and Biotechnology, Seoul National University, Seoul 151-921, Korea \\ ${ }^{3}$ Research Institute of Agriculture and Life Sciences, Seoul National University, Seoul 151-921, Korea
}

\begin{abstract}
Growth and flowering of Cymbidium 'Red Fire' and 'Yokihi' plants were examined in a greenhouse with cooling systems in summer, and with night interruption (NI) lighting in winter as a forcing culture system. The greenhouse was divided into two sections with separate cooling controls during the summer season. One section was cooled by a mist system (mist), while the other section was cooled by a shade screen (shade). During the winter, the greenhouse was redivided into three sections within each cooling system. Plants were grown with NI either at a low light intensity of 3-7 $\mu \mathrm{mol} \cdot \mathrm{m}^{-2} \cdot \mathrm{s}^{-1}$ (LNI) or a high light intensity of $120 \mu \mathrm{mol} \cdot \mathrm{m}^{-2} \cdot \mathrm{s}^{-1}$ (HNI) using high-pressure sodium lamps during the 22:00-02:00 HR. The control plants were grown under $9 \mathrm{~h}$ short-day condition. NI for 16 weeks and cooling for 9 weeks were employed twice during the 2 years of the experimental period. The air temperature was approximately $2^{\circ} \mathrm{C}$ lower in the mist than in the shade and the relative humidity was 80 $\pm 5 \%$ in the mist compared to $55 \pm 5 \%$ in the shade. The daily light integral in the mist section was $48 \%$ higher than in the shade section. The time from initial planting to flowering pseudobulb emergence decreased with both LNI and HNI for both cultivars, regardless of the cooling treatments. Under NI conditions, however, between $60 \%$ and $100 \%$ of plants of both cultivars flowered in the mist, whereas no or $20 \%$ of 'Red Fire' or 'Yokihi' plants, respectively, flowered in the shade treatment over 2 years. Plants grown under the mist had bigger pseudobulbs than those grown in the shade under both NI treatments. These results show that commercial use of NI in winter and a mist cooling system in summer would decrease crop production time to 2 years and increase profits in Cymbidium forcing culture.
\end{abstract}

Additional key words: daily light integral, orchid, photoperiod, temperature

\section{Introduction}

Flowering in orchid plants is regulated by both internal factors and environmental signals such as daylength and temperature (Cerdan and Chory, 2003). Different species of orchids exhibit sensitivity to daylength in various ways, and yet small changes in daylength are critical for the growth and flowering of plants in the genera Cattleya, Dendrobium, and Phalaenopsis (Bhattacharjee, 1979). Cattleya ladiata and Zygopetalum Redvale 'Fire Kiss' flowered under short-day (SD) (Lopez and Runkle, 2005), while artificial lighting during the middle of the night (night interruption,
NI) promoted the growth and/or flowering of Cymbidium 'Red Fire' and 'Yokihi' (An et al., 2012; Kim et al., 2011) as well as some herbaceous long-day (LD) plants (Blanchard and Runkle, 2010; Oh et al., 2008; Yamada et al., 2008).

Cymbidium, a terrestrial orchid species, is commonly grown as a commercial potted or cut plant because of long postharvest life. Low temperatures are required for flower bud initiation regardless of daylength in Cymbidium (Rotor, 1952). The temperature tolerance of Cymbidium, which is a native of the Himalayas to tropical regions in Asia, varies depending on its origin. The growth of Cymbidium originating in China is accelerated at daytime and nighttime

\footnotetext{
*Comesponding author: kisun@snu.ac.kr

※ Received 14 April 2014; Revised 28 April 2014; Accepted 8 June 2014. This study was supported by the National Research Foundation of Korea funded by the Ministry of Education, Science, and Technology and a research grant from Seoul Woman's University (2014).

(C) 2014 Korean Society for Horticultural Science
} 
temperatures of $30^{\circ} \mathrm{C}$ and $25^{\circ} \mathrm{C}$, respectively. However, a positive diurnal fluctuation of $10-14^{\circ} \mathrm{C}$ is required for flower initiation in a large-flowered Cymbidium species from the Himalayas and China (Lopez and Runkle, 2005). Daytime and nighttime temperatures appeared to have an effect on flower induction in some Cymbidium species (Pridgeon, 1992; Rotor, 1952; Went, 1957).

In summer, several Cymbidium hybrids are commonly transported from lowland production areas to higher elevations. This strategy helps to avoid high-temperature stress during vegetative growth and exposes plants to lower temperatures and higher light intensities for flower initiation (Ichihashi, 1997). However, plant quality is often reduced during transportation and this can be costly for growers. Although flowering of many Cymbidium spp. can be manipulated using lower temperatures during the summer period, crop in a greenhouse is negatively affected by high temperature, which decreases yield and product quality. A number of cooling techniques, such as natural ventilation, white-shading, shade screens, and evaporative cooling (e.g. wet pad-fan, misting, and fogging systems) are used, instead of transporting the plants to higher altitudes, to maintain the temperature and humidity of a greenhouse at acceptable levels during hot periods (Perdigones et al., 2008).

In our previous study, NI in winter during 2 years promoted vegetative growth and consequently hastened flowering within 2 years compared to the 3-4 years of general cultivation with natural light conditions in Cymbidium 'Red Fire' and 'Yokihi' (An et al., 2012; Kim et al., 2011). However, no experiments were performed regarding summer environment controlling methods of Cymbidium flower induction and development in commercial greenhouses. In this study, we compared the effects of two cooling techniques, mist and shade in a greenhouse during summer period, on the growth and flowering of Cymbidium 'Red Fire' and 'Yokihi' under NI conditions.

\section{Materials and Methods}

\section{Plants and Growth Conditions}

The 'Red Fire' and 'Yokihi' varieties of Cymbidium hybrids (Mukoyama Orchids Co., Ltd., Koshushi, Japan) were transplanted into $10 \mathrm{~cm}$ pots containing $100 \%$ chopped coconut husk and then re-transplanted into $16 \mathrm{~cm}$ pots after 4 months of growth. The plants were grown in a commercial greenhouse (Sang-Il Orchid Farm, Hwaseong, Korea). The plants were irrigated daily with tap water. A total of $5 \mathrm{~g}$ of controlled-release fertilizer 13N-5.7P-10.8K (Mukoyama
Orchids Co., Ltd.) was placed on the top of the growing medium. The fertilizer was applied at different times during production: at transplanting and upon emergence of the first and the second flowering pseudobulbs. Supplemental fertilizers were applied bimonthly to the plants using a sprinkler. The supplemental fertilizer was composed of $\mathrm{Ca}\left(\mathrm{NO}_{3}\right)_{2} \cdot 4 \mathrm{H}_{2} \mathrm{O}$, Fe-EDTA, $\mathrm{MgSO}_{4} \cdot 7 \mathrm{H}_{2} \mathrm{O}, \mathrm{MnSO}_{4}, \mathrm{ZnSO}_{4} \cdot 7 \mathrm{H}_{2} \mathrm{O}, \mathrm{H}_{3} \mathrm{BO}_{3}, \mathrm{CuSO}_{4}$. $5 \mathrm{H}_{2} \mathrm{O}$, and $\mathrm{Na}_{2} \mathrm{MoO}_{4} \cdot 2 \mathrm{H}_{2} \mathrm{O}$ and provided $472,3.44,316,1.63$, $1.15,1.24,0.1$, and $0.09 \mathrm{~g} \cdot \mathrm{m}^{-3}$ of each nutrient (electrical conductivity $1.0 \mathrm{dS} \cdot \mathrm{cm}^{-1}$ ), respectively.

\section{Experimental Design}

The NI (16 weeks per each year) and cooling treatments ( 9 weeks per each year) were conducted twice during the 2 years of experimental period. In the first year (2009), twenty plants were grown in a NI treatment group. Ten plants from each NI treatment group were moved to the mist condition, while the other ten plants were placed under the shade condition. In the second year (2010), all of the plants treated with both the NI and summer cooling were re-exposed to the same NI and summer cooling as in the first year (2009).

\section{NI Treatment}

All Cymbidium plants received supplemental lighting from high-pressure sodium lamps (SKL-01, GEO, Hwasung, Korea) from 22:00 to 02:00 $\mathrm{h}$. The greenhouse was divided into three experimental sections within each cooling system. The potted plants were placed at different distances from the lamps to differentiate effects of light intensities. All treatments received a natural photoperiods that was truncated to $9 \mathrm{~h}$ through the use of retractable opaque black cloth that covered the greenhouse structure from 17:00 to 08:00 h. The three photoperiod treatments were $9 \mathrm{~h}$ short-day (control) or a $9 \mathrm{~h}$ with NI lighting at a low intensity $\left(3-7 \mu \mathrm{mol} \cdot \mathrm{m}^{-2} \cdot \mathrm{s}^{-1}\right.$; LNI) or a high intensity $(120$ $\left.\mu \mathrm{mol} \cdot \mathrm{m}^{-2} \cdot \mathrm{s}^{-1} ; \mathrm{HNI}\right)$. Light intensity for NI was measured using a Li-Cor 1400 portable sensor (Li-Cor, Co., Inc., Lincoln, NE, USA). The first NI treatment (2009) began immediately after transplanting and lasted for 16 weeks (Feb. to May 2009) and the second NI treatment (2010) began 38 weeks after transplanting and lasted for another 16 weeks (Nov. 2009 to Feb. 2010). The average day/night temperatures during the NI treatment were $22 / 15^{\circ} \mathrm{C}$ and $19 / 12^{\circ} \mathrm{C}$ for the first and the second year, respectively. Temperature was measured with a data logger (NJ2005, Nongjung, Seoul, Korea). Environmental conditions such as air temperature, relative humidity $(\mathrm{RH})$, and $\mathrm{CO}_{2}$ con- 
centration were kept similar in all sections of the greenhouse during the experimental period.

\section{Summer Cooling Treatment}

Cooling treatments were applied twice during the 2 years of experimental period. The plants were subjected to the summer cooling treatments from June to August for 9 weeks in 2009 and 2010. The $80 \mathrm{~m}$ long greenhouse was divided into two identical sections. One of the sections was cooled by a shade screen (shade), while the other was cooled using a mist system (mist). The shade screen was polyester with nominal values of $50 \%$ shade. The greenhouse was ventilated by openings in the roof and the sides. The greenhouse was equipped with a single continuous roof vent $(79.5 \mathrm{~m}$ long $\times 4 \mathrm{~m}$ wide) located on the north side of the roof along with two side vents. All vents were completely open all the time during the summer experimental period.

The mist cooling equipment consisted of a high-pressure water vapour distribution system comprising three mist and fan modules, each with a capacity to cover $100 \mathrm{~m}^{2}$. Vertical air mixing fans were used to facilitate homogeneous water vapour distribution inside the greenhouse. A circular ring with eight nozzles for the distribution of mist droplets was placed above the fan outlet. Each module had a total capacity of approximately $160 \mathrm{~L} \cdot \mathrm{h}^{-1}$ at a working pressure of approximately 40 bars. Based on the previous experimental data showing that greenhouse air temperature levels were below the upper limit of optimal temperature $\left(25 \pm 1^{\circ} \mathrm{C}\right)$ necessary for the crop before 10:00 $\mathrm{h}$ and after 16:00 $\mathrm{h}$, the mist system and shade screen were scheduled to operate continuously from 10:00 to $16: 00 \mathrm{~h}$.

Dry and wet temperature sensors placed close to the plant canopy in each greenhouse section were used to monitor the air temperatures and RH. A Nongjungcyber greenhouse computer with a data logger (NJ2005, Nongjung, Seoul, Korea) for temperature and another data logger (M100, Hanyoung, Seoul, Korea) for RH were connected for the recording and storage of climatic data every 30 min. The photosynthetic photon flux (PPF) was measured every 30 min using an Li-Cor 1400 portable sensor (Li-Cor, Co., Inc., Lincoln, NE, USA) from 09:00 to 17:00 h.

\section{Data Collection}

Climatic data collected in summer were averaged over 30 min intervals, covering the period from 05:00 to 21:00 h. Due to the similar responses to temperature, $\mathrm{RH}$, and PPF in most days, only selected data collected during representative sunny days were presented. The data selected for analysis were recorded on July 5, July 23, and August 13 in 2009 and June 23, July 13, and August 19 in 2010.

The number of leaves, leaf length, leaf width, the number of pseudobulbs, and pseudobulb diameter were measured monthly. The longest leaf measured from the base of the pseudobulb was used to represent leaf length. Pseudobulb diameter was measured at the widest point of the flowering pseudobulb using a digital caliper (ABS Digimatic Caliper; Mitutoyo Co., Ltd., Tsukuba, Japan). The time from the start of the treatments to flowering pseudobulb emergence and flowering percentage after the NI and cooling treatments were recorded. The time to visible inflorescence (VI) from the start of the treatments and the number of flowers were also measured. The time at which the first floret was fully open was considered the flowering time. However, all the 'Yokihi' plants grown under HNI in combination with the shade cooling system died as a result of soft rot disease in August, 2010. Therefore no more data were collected for this treatment (Table 2).

\section{Statistical Analysis}

Statistical analyses were performed using SAS for Windows v8 (SAS Institute Inc., Cary, NC, USA). Differences in growth and flowering among the treatments were assessed using a Tukey's honestly significant difference test at $p<0.05$. Regression and graph module analyses were performed using the Sigma Plot (Systat Software, Inc., Chicago, IL, USA).

\section{Results}

\section{Greenhouse Microclimate in Summer}

The average day temperature between 10:00 and 16:00 $\mathrm{h}$ in the mist-cooled section was $2.3^{\circ} \mathrm{C}$ and $2.7^{\circ} \mathrm{C}$ lower than the average day temperature in the shade section in 2009 and 2010, respectively (Fig. 1). The night temperature was not controlled, yet naturally remained at $20 \pm 2^{\circ} \mathrm{C}$ in summer and $10 \pm 2^{\circ} \mathrm{C}$ in winter. In the mist-cooled section in 2010 , the air temperature reached about $28^{\circ} \mathrm{C}$ after 11:00 h, remained at this level until 14:00 $\mathrm{h}$ and then started to decrease (Fig. 1B). In the shade in 2010, it reached a mean maximum value of $35.9^{\circ} \mathrm{C}$ at $15: 00 \mathrm{~h}$. The average leaf temperature between 10:00 and 16:00 $\mathrm{h}$ in 2010 was $29.2^{\circ} \mathrm{C}$ in the mist and $31.8^{\circ} \mathrm{C}$ in the shade (data not shown). An analysis of variance revealed significant differences between the microclimate in the different cooling treatments. RH was higher under mist conditions $(80 \pm$ $5 \%)$ than under shade conditions (55 $\pm 5 \%$ ) in both years (Fig. 2). The average PPF values during the summer period 


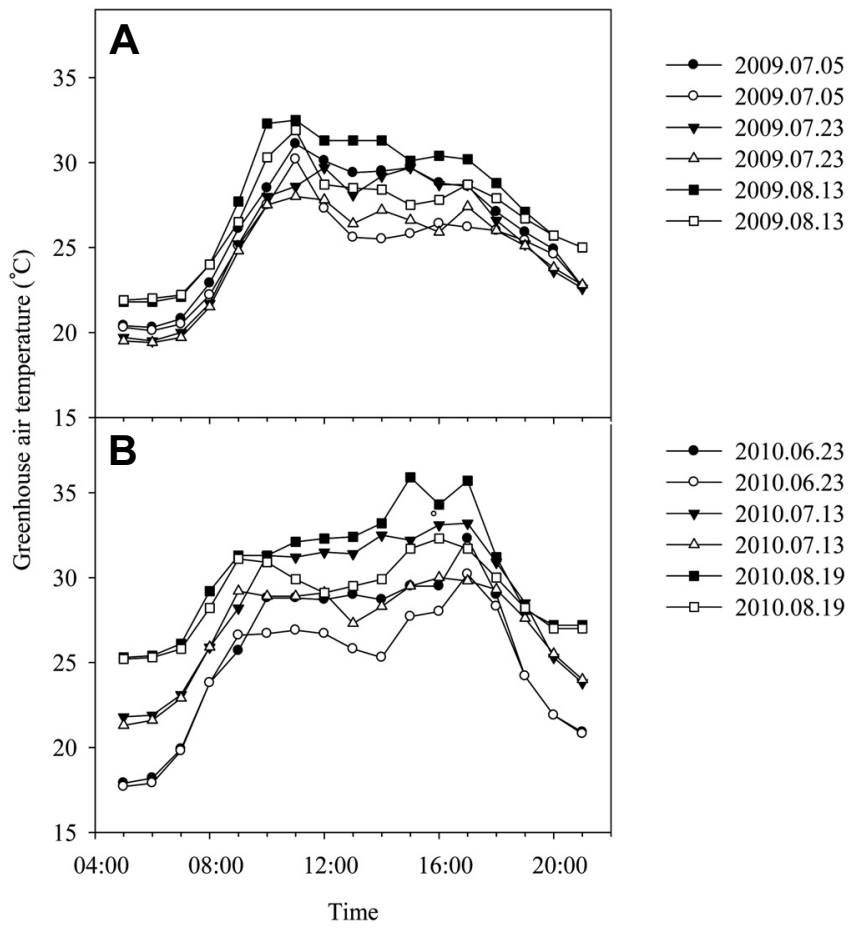

Fig. 1. Air temperature inside the two greenhouse sections in the summers of 2009 (A) and 2010 (B). Open symbol $=$ mist condition; closed symbol $=$ shade condition.

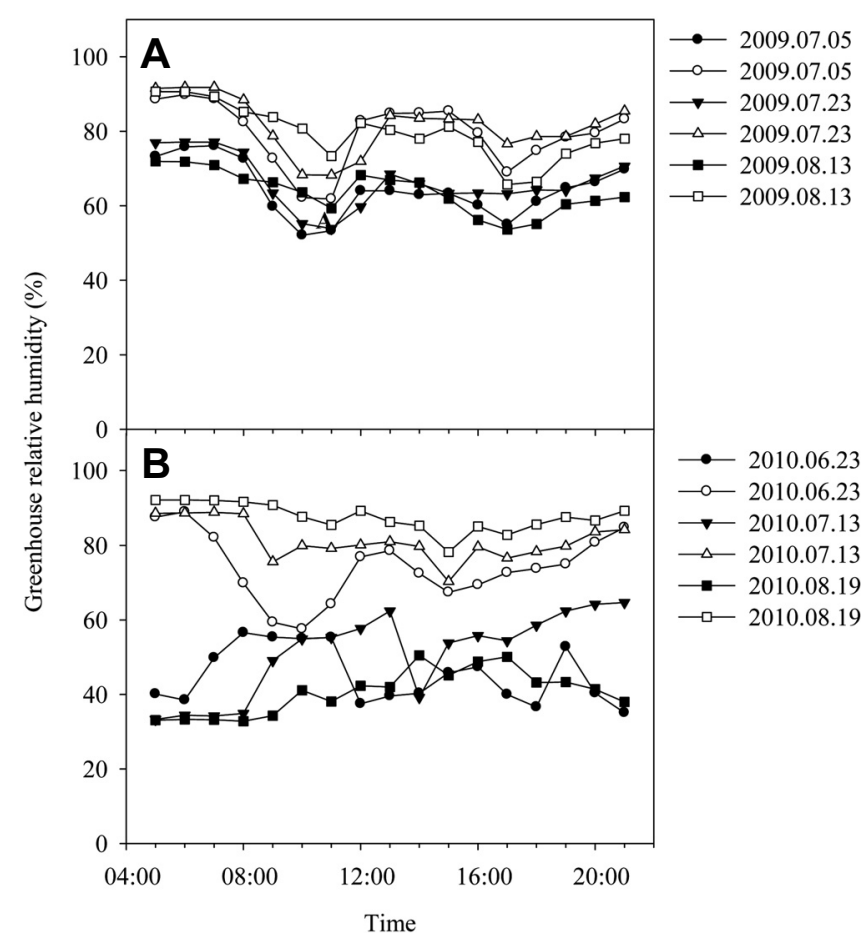

Fig. 2. Relative humidity inside the two greenhouse sections in the summers of 2009 (A) and 2010 (B). Open symbol $=$ mist condition; closed symbol $=$ shade condition .

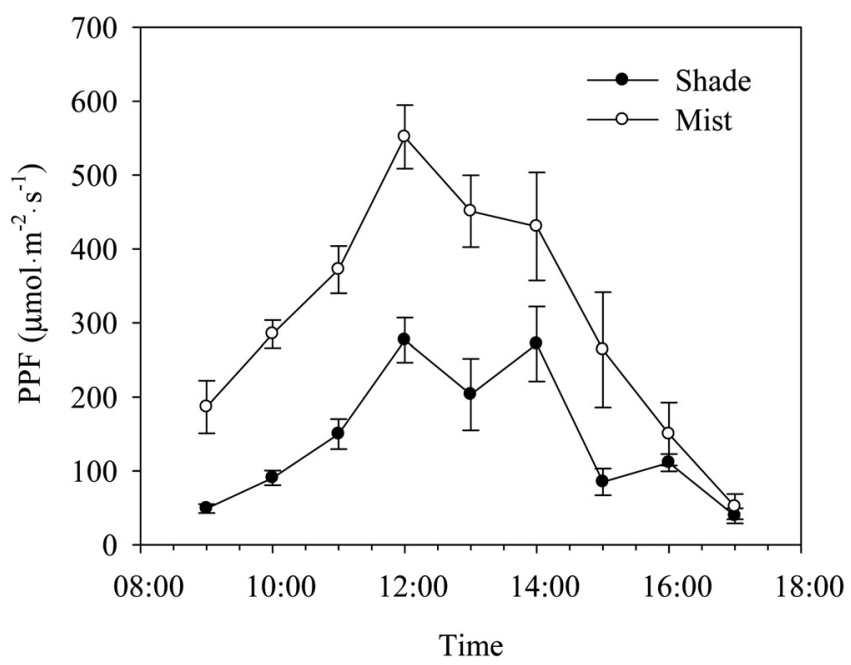

Fig. 3. Changes in the greenhouse average photosynthetic photon flux (PPF) under mist and shade conditions from 09:00-17:00 $\mathrm{h}$ in 2010.

from July to August were 305 and $142 \mu \mathrm{mol} \cdot \mathrm{m}^{-2} \cdot \mathrm{s}^{-1}$ in mist and shade, respectively (Fig. 3). Hence, the average daily light integral (DLI) in 2010 in summer (July to August) was 8.8 and $4.1 \mathrm{~mol} \cdot \mathrm{m}^{-2} \cdot \mathrm{d}^{-1}$ at plant height in mist and shade, respectively.

\section{Plant Growth}

The number of pseudobulbs significantly $(p<0.01)$ increased under HNI condition in the second year NI treatment compared to plants grown under control condition regardless of the type of cooling treatments (Table 1). After the first year treatments, the pseudobulbs were bigger on plants grown under HNI and mist conditions than under control and mist conditions. After the second year treatment, the pseudobulbs were significantly $(p<0.05)$ larger in plants grown under HNI and mist conditions compared to plants grown under $\mathrm{HNI}$ and shade conditions. No significant differences were found in the number of leaves, leaf length, and leaf width in 'Red Fire' plants regardless of the type of cooling with NI treatments (Table 1). For 'Yokihi', the pseudobulb diameter was the largest $(5.89 \mathrm{~cm})$ in the HNI combined with mist (Table 2). Leaf length and width significantly $(p<0.001)$ increased under HNI combined with mist at the end of 2009 compared to those grown under control and LNI conditions. Leaves were longer in shaded plants compared to misted plants under the LNI condition after the first year (Table 2). No significant difference was found in the number of pseudobulbs in both years. No data were collected under the HNI combined 
Table 1. Effects of cooling system and night interruption (NI) on the growth of Cymbidium 'Red Fire' after the first and the second year of treatments.

\begin{tabular}{|c|c|c|c|c|c|c|}
\hline $\begin{array}{l}\text { Cooling } \\
\text { system }^{z}\end{array}$ & $\mathrm{NI}^{\mathrm{y}}$ & $\begin{array}{l}\text { No. of } \\
\text { leaves }\end{array}$ & $\begin{array}{l}\text { Leaf length } \\
(\mathrm{cm})\end{array}$ & $\begin{array}{l}\text { Leaf width } \\
(\mathrm{cm})\end{array}$ & $\begin{array}{c}\text { No. of } \\
\text { pseudobulbs }\end{array}$ & $\begin{array}{c}\text { Pseudobulb } \\
\text { diameter }(\mathrm{cm})\end{array}$ \\
\hline \multicolumn{7}{|c|}{ The first year (2009) } \\
\hline \multirow[t]{3}{*}{ Mist } & Control & $13.5 a b^{x}$ & $28.5 \mathrm{c}$ & $1.79 \mathrm{a}$ & $1.33 \mathrm{ab}$ & $1.81 \mathrm{c}$ \\
\hline & LNI & $14.1 \mathrm{a}$ & $33.9 \mathrm{ab}$ & $2.05 \mathrm{a}$ & $1.67 \mathrm{ab}$ & $2.06 \mathrm{ab}$ \\
\hline & HNI & $13.9 \mathrm{a}$ & $32.9 \mathrm{abc}$ & $2.78 \mathrm{a}$ & $1.83 \mathrm{a}$ & $2.22 \mathrm{a}$ \\
\hline \multirow[t]{3}{*}{ Shade } & Control & $12.3 \mathrm{~b}$ & $32.4 \mathrm{bc}$ & $1.87 \mathrm{a}$ & $1.08 \mathrm{~b}$ & $1.90 \mathrm{bc}$ \\
\hline & LNI & $13.3 \mathrm{ab}$ & $35.4 \mathrm{ab}$ & $1.99 \mathrm{a}$ & $1.33 \mathrm{ab}$ & $1.90 \mathrm{~b}$ \\
\hline & HNI & $14.0 \mathrm{a}$ & $37.3 \mathrm{a}$ & $1.95 \mathrm{a}$ & $1.50 \mathrm{ab}$ & $2.08 \mathrm{ab}$ \\
\hline \multicolumn{7}{|c|}{ Significance } \\
\hline NI & & $* *$ & $* * *$ & NS & $*$ & $* * *$ \\
\hline Cooling & & $*$ & $* *$ & NS & $*$ & NS \\
\hline Cooling & & NS & NS & NS & NS & $*$ \\
\hline \multicolumn{7}{|c|}{ The second year (2010) } \\
\hline \multirow[t]{3}{*}{ Mist } & Control & $30.1 \mathrm{a}$ & $62.9 \mathrm{bc}$ & $2.14 \mathrm{a}$ & $2.42 \mathrm{bc}$ & $3.21 \mathrm{ab}$ \\
\hline & LNI & $29.0 \mathrm{a}$ & $71.0 \mathrm{a}$ & $2.42 \mathrm{a}$ & $2.67 \mathrm{~b}$ & $4.86 \mathrm{a}$ \\
\hline & HNI & $30.4 \mathrm{a}$ & $60.8 \mathrm{c}$ & $2.44 \mathrm{a}$ & $4.58 \mathrm{a}$ & $4.86 \mathrm{a}$ \\
\hline \multirow[t]{3}{*}{ Shade } & Control & $31.5 \mathrm{a}$ & $70.5 \mathrm{ab}$ & $2.15 \mathrm{a}$ & $1.83 \mathrm{c}$ & $3.32 \mathrm{~b}$ \\
\hline & LNI & $31.7 \mathrm{a}$ & $77.3 \mathrm{a}$ & $2.38 \mathrm{a}$ & $2.41 \mathrm{bc}$ & $4.18 a b$ \\
\hline & HNI & $31.1 \mathrm{a}$ & $70.0 \mathrm{c}$ & $2.38 \mathrm{a}$ & $3.00 \mathrm{~b}$ & $4.06 \mathrm{~b}$ \\
\hline \multicolumn{7}{|c|}{ Significance } \\
\hline \multicolumn{2}{|c|}{ NI } & NS & $* * *$ & $* *$ & $* * *$ & $* * *$ \\
\hline \multicolumn{2}{|c|}{ Cooling } & $*$ & $* * *$ & NS & $* * *$ & $* *$ \\
\hline \multicolumn{2}{|c|}{ Cooling $\times$ NI } & NS & NS & NS & $* *$ & $*$ \\
\hline
\end{tabular}

${ }^{\mathrm{z}_{T}}$ The plants were grown under mist or shade cooling systems for 9 weeks from June to August in 2009 and 2010.

${ }^{\mathrm{y}}$ The plants were grown under NI (16 weeks per each year) at $3-7 \mu \mathrm{mol} \cdot \mathrm{m}^{-2} \cdot \mathrm{s}^{-1}$ (LNI) or at $120 \mu \mathrm{mol} \cdot \mathrm{m}^{-2} \cdot \mathrm{s}^{-1}$ (HNI) with high-pressure sodium (HPS) lamps. Control plants were grown under short-day condition with opaque cloth.

${ }^{x}$ Mean separation within columns in each year by Tukey's honestly significant difference test at $p<0.05$.

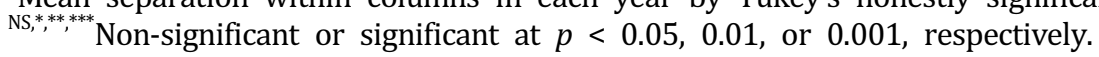

with shading conditions in 2010 (Table 2).

\section{Flowering}

The time from initial planting to the time of flowering pseudobulb emergence decreased with mist cooling system by more than 12 weeks and 17 weeks than shade under LNI and HNI conditions, respectively, for 'Red Fire' (Table 3 ). The $60 \%$ of the plants of both cultivars flowered under LNI condition in the mist, and up to $100 \%$ of the plants for 'Yokihi' flowered under HNI condition. However, no 'Red Fire' plants flowered in the shade and only $20 \%$ of shade-cooled 'Yokihi' plants flowered under LNI (Table 3). Plants grown under LNI and HNI and mist conditions produced flowers. Time to VI decreased in the plants grown under HNI condition than under LNI condition in 'Red Fire' plants, whereas no significant differences was found in time to flowering in both cultivars. Both cultivars of Cymbidium grown at daytime temperature of $27^{\circ} \mathrm{C}$ or higher under shade condition has showed leaf necrosis and inflorescence abortion. In addition, mature 'Yokihi' plants grown under HNI died due to soft rot in early August of 2010 (Table 3).

\section{Discussion}

The average day temperature in the mist-cooled section 
Table 2. Effects of cooling system and night interruption (NI) on the growth of Cymbidium 'Yokihi' after the first and the second year of treatments.

\begin{tabular}{|c|c|c|c|c|c|c|}
\hline $\begin{array}{l}\text { Cooling } \\
\text { system }^{z}\end{array}$ & $\mathrm{NI}^{\mathrm{y}}$ & $\begin{array}{l}\text { No. of } \\
\text { leaves }\end{array}$ & $\begin{array}{l}\text { Leaf length } \\
(\mathrm{cm})\end{array}$ & $\begin{array}{l}\text { Leaf width } \\
(\mathrm{cm})\end{array}$ & $\begin{array}{c}\text { No. of } \\
\text { pseudobulbs }\end{array}$ & $\begin{array}{c}\text { Pseudobulb } \\
\text { diameter }(\mathrm{cm})\end{array}$ \\
\hline \multicolumn{7}{|c|}{ The first year (2009) } \\
\hline \multirow[t]{3}{*}{ Mist } & Control & $14.6 a b c^{x}$ & $29.7 \mathrm{c}$ & $1.77 \mathrm{~b}$ & $1.53 \mathrm{ab}$ & $1.95 \mathrm{a}$ \\
\hline & LNI & $14.0 \mathrm{c}$ & $28.0 \mathrm{c}$ & $1.75 \mathrm{~b}$ & $1.62 \mathrm{ab}$ & $1.89 \mathrm{a}$ \\
\hline & HNI & 15.9 a & $34.1 \mathrm{~b}$ & $2.05 \mathrm{a}$ & $1.77 \mathrm{a}$ & $2.07 \mathrm{a}$ \\
\hline \multirow[t]{3}{*}{ Shade } & Control & $15.8 \mathrm{ab}$ & $36.2 \mathrm{ab}$ & $1.89 \mathrm{ab}$ & $1.32 \mathrm{ab}$ & $1.95 \mathrm{a}$ \\
\hline & LNI & $15.5 \mathrm{abc}$ & 36.7 a & $1.84 \mathrm{~b}$ & $1.32 \mathrm{ab}$ & $1.99 \mathrm{a}$ \\
\hline & HNI & $14.2 \mathrm{bc}$ & $35.7 \mathrm{ab}$ & $1.84 \mathrm{~b}$ & $1.17 \mathrm{~b}$ & $1.88 \mathrm{a}$ \\
\hline \multicolumn{7}{|c|}{ Significance } \\
\hline $\mathrm{NI}$ & & NS & $* * *$ & $* *$ & NS & NS \\
\hline Cooling & & NS & $* * *$ & $*$ & $* *$ & NS \\
\hline Cooling & & $* * *$ & $* * *$ & $* * *$ & NS & NS \\
\hline \multicolumn{7}{|c|}{ The second year (2010) } \\
\hline \multirow[t]{3}{*}{ Mist } & Control & $33.8 \mathrm{ab}$ & $65.6 \mathrm{c}$ & $2.36 \mathrm{c}$ & $2.83 \mathrm{a}$ & $4.20 \mathrm{~b}$ \\
\hline & LNI & $34.5 \mathrm{ab}$ & $71.5 \mathrm{bc}$ & $2.41 \mathrm{bc}$ & $2.83 \mathrm{a}$ & $4.45 \mathrm{~b}$ \\
\hline & HNI & 37.8 a & $74.3 \mathrm{~b}$ & $2.75 \mathrm{a}$ & $2.83 \mathrm{a}$ & $5.89 \mathrm{a}$ \\
\hline \multirow[t]{3}{*}{ Shade } & Control & $31.5 \mathrm{~b}$ & $70.5 \mathrm{bc}$ & $2.47 \mathrm{bc}$ & $1.83 \mathrm{a}$ & $3.32 \mathrm{c}$ \\
\hline & LNI & $37.8 \mathrm{a}$ & $82.0 \mathrm{a}$ & $2.68 \mathrm{ab}$ & $2.08 \mathrm{a}$ & $3.83 \mathrm{bc}$ \\
\hline & HNI & $-w$ & - & - & - & - \\
\hline \multicolumn{7}{|c|}{ Significance } \\
\hline \multicolumn{2}{|c|}{$\mathrm{NI}$} & $* *$ & $* * *$ & $* *$ & NS & $* * *$ \\
\hline \multicolumn{2}{|c|}{ Cooling } & NS & $* * *$ & $* *$ & NS & $* * *$ \\
\hline \multicolumn{2}{|c|}{ Cooling $\times$ NI } & $*$ & NS & NS & NS & NS \\
\hline
\end{tabular}

${ }^{\mathrm{z}}$ The plants were grown under mist or shade cooling systems for 9 weeks from June to August in 2009 and 2010.

${ }^{\mathrm{y}}$ The plants were grown under NI (16 weeks per each year) at 3-7 $\mu \mathrm{mol} \cdot \mathrm{m}^{-2} \cdot \mathrm{s}^{-1}$ (LNI) or at $120 \mu \mathrm{mol} \cdot \mathrm{m}^{-2} \cdot \mathrm{s}^{-1}$ (HNI) with high-pressure sodium (HPS) lamps. Control plants were grown under short-day condition with opaque cloth.

${ }^{x}$ Mean separation within columns in each year by Tukey's honestly significant difference test at $p<0.05$.

${ }^{w}$ Plants showing lower than a $30 \%$ survival rate were not included in the analysis.

$\mathrm{NS}, * * * * * * * *_{N}$ Non-significant or significant at $p<0.05,0.01$, or 0.001 , respectively.

was $2.5^{\circ} \mathrm{C}$ lower than the day temperature in the shade section, while the RH was $25 \%$ higher in the mist section than in the shade section, demonstrating that evaporative cooling systems not only decrease air temperature but also increase humidity in the greenhouse (Arbel et al., 1999). The air temperature and vapour pressure deficit significantly decreased under the use of a mist system for greenhouse cooling in cultivation of Rosa hybrida cv. First Red (Katsoulas et al., 2001) and Lycopersicon esculentum (Romero-Aranda et al., 2002). A further advantage of the mist-cooling is the establishment of uniform temperature and humidity conditions throughout the greenhouse (Perdigones et al., 2008). Withner (1974) reported that mist cooling is effective due to both the cool initial temperature of the water and its evaporative effects on the leaf surfaces in Cymbidium. In this study, the plants grown under shade condition did not flower with either the LNI or HNI conditions, while the plants under mist condition flowered within 2 years regardless of NI treatments. Cymbidium need to reach a certain growth stage which is represented by the minimum pseudobulb size before they turn into the reproductive stage (Kim et al., 2011, 2013). Increasing pseudobulb diameter is closely related to the photosynthesis which is influenced by temperature and light (Ng and Hew, 
Table 3. Effects of cooling system and night interruption (NI) on the flowering of Cymbidium 'Red Fire' and 'Yokihi' after 2 years of treatments.

\begin{tabular}{|c|c|c|c|c|c|c|}
\hline $\begin{array}{l}\text { Cooling } \\
\text { system }^{z}\end{array}$ & $\mathrm{NI}^{\mathrm{y}}$ & $\begin{array}{l}\text { Time to emergence } \\
\text { of flowering } \\
\text { pseudobulb (weeks) }\end{array}$ & $\begin{array}{l}\text { Time to } \mathrm{VI}^{\mathrm{X}} \\
\text { (weeks) }\end{array}$ & $\begin{array}{l}\text { Time to } \\
\text { flowering } \\
\text { (weeks) }\end{array}$ & $\begin{array}{l}\text { No. of } \\
\text { flowers } \\
\text { /pot }\end{array}$ & $\begin{array}{l}\text { Flowering } \\
\text { percentage }\end{array}$ \\
\hline \multicolumn{7}{|l|}{ 'Red Fire' } \\
\hline \multirow[t]{2}{*}{ Mist } & Control & $51.0 \mathrm{a}^{\mathrm{w}}$ & $-\mathrm{v}$ & - & - & 0 \\
\hline & LNI & $34.3 \mathrm{bc}$ & $82.3 \mathrm{a}$ & 103.9 a & $9.6 \mathrm{a}$ & 60 \\
\hline \multirow{2}{*}{ Shade } & LNI & $46.4 \mathrm{a}$ & - & - & - & 0 \\
\hline & $\mathrm{HNI}$ & $43.4 \mathrm{ab}$ & - & - & - & 0 \\
\hline \multicolumn{7}{|l|}{ Significance } \\
\hline $\mathrm{NI}$ & & $* * *$ & $* * *$ & NS & NS & \\
\hline \multicolumn{7}{|l|}{ 'Yokihi' } \\
\hline \multirow[t]{3}{*}{ Mist } & Control & $45.0 \mathrm{a}$ & - & - & - & 0 \\
\hline & LNI & $30.6 \mathrm{~b}$ & $81.1 \mathrm{a}$ & $106.2 \mathrm{a}$ & $18.8 \mathrm{a}$ & 60 \\
\hline & HNI & $27.9 \mathrm{~b}$ & $78.2 \mathrm{a}$ & $102.5 \mathrm{a}$ & $30.0 \mathrm{a}$ & 100 \\
\hline \multirow[t]{3}{*}{ Shade } & Control & $46.6 \mathrm{a}$ & - & - & - & 0 \\
\hline & LNI & $40.4 \mathrm{a}$ & - & - & - & 20 \\
\hline & $\mathrm{HNI}$ & $37.4 \mathrm{ab}$ & - & - & - & 0 \\
\hline \multicolumn{7}{|l|}{ Significance } \\
\hline $\mathrm{NI}$ & & $* * *$ & NS & NS & NS & \\
\hline
\end{tabular}

${ }^{\mathrm{z}_{\text {The }}}$ plants were grown in the mist and shade for 9 weeks from June to August in 2009 and 2010.

${ }^{\mathrm{y}}$ The plants were grown under NI $\left(16\right.$ weeks per each year) at $3-7 \mu \mathrm{mol} \cdot \mathrm{m}^{-2} \cdot \mathrm{s}^{-1}$ (LNI) or at $120 \mu \mathrm{mol} \cdot \mathrm{m}^{-2} \cdot \mathrm{s}^{-1}(\mathrm{HNI}) \mathrm{with}$ high-pressure sodium (HPS) lamps. Control plants were grown under short-day condition with opaque cloth.

${ }^{\mathrm{x}}$ VI, Visible inflorescence.

${ }^{\mathrm{w}}$ Mean separation within columns by Tukey's honestly significant difference test at $p<0.05$.

${ }^{v}$ Plants did not flower within 2 years after the start of the treatments. Plants with less than $30 \%$ flowering were not included in the analysis.

${ }_{\mathrm{NS}, * * * * * *}^{*}$ Non-significant or significant at $p<0.01$ or 0.001 , respectively.

2000). The plants grown in the mist-cooling treatment had bigger pseudobulbs than those grown in the shade treatment under both NI treatments (Tables 1 and 2). Kim et al. (2011) reported that pseudobulbs with a minimum diameter of $5.2 \mathrm{~cm}$ for 'Red Fire' and $4.4 \mathrm{~cm}$ for 'Yokihi' were required for the flowering. However, our data indicate that the plants required at least $4.86 \mathrm{~cm}$ pseudobulbs diameter in 'Red Fire' and $4.2 \mathrm{~cm}$ in 'Yokihi' for flowering in this study. In Miltoniopsis, 90\% of the pseudobulbs initiated inflorescences when the pseudobulb diameter was $3.1 \mathrm{~cm}$ or greater (Lopez and Runkle, 2006), and in Odontioda, a temperature maintained at $17^{\circ} \mathrm{C}$ yielded the greatest increase in pseudobulb diameter (Kubota et al., 2005).

Cymbidium 'Yokihi' plants grown under HNI died due to soft rot by high temperature during the second year treatment (Table 3). Similarly, Odontioda 'Velano' grown at $28 / 18^{\circ} \mathrm{C}(12 \mathrm{~h}$ day $/ 12 \mathrm{~h}$ night) developed yellow leaves within 8 weeks and died within 24 weeks (Kubota et al., 
2005). High temperature response has been also reported in the Zygopetalum 'Fire Kiss', in which the flower buds on plants grown at temperatures greater than $25^{\circ} \mathrm{C}$ developed necrotic lesions and aborted within 20 days (Lopez and Runkle, 2004). Although plants can tolerate high temperatures $\left(>27^{\circ} \mathrm{C}\right.$ ), such conditions favour soft rot infection (Wright and Triggs, 2009). Klement (1990) found that high temperatures $\left(>30^{\circ} \mathrm{C}\right.$ ) can deplete $\mathrm{O}_{2}$ stored in plant tissues due to respiration.

Cymbidium 'Red Fire' and 'Yokihi' should be grown at temperatures of $<27^{\circ} \mathrm{C}$ in summer to prevent heat stress and inflorescence abortion. Although the parents of 'Red Fire' and 'Yokihi' have not been reported, these cultivars required relatively high temperatures for flower initiation. Inflorescence initiation in summer and flower development before winter also occurred in the Cymbidium 'ShiratamaNishiki' (Kosugi et al., 1971). In general, flowering occurs only after the termination of vegetative growth in the pseudobulbs and is regulated by temperature in many orchid species (Chae, 2002; Ng and Hew, 2000). Miltoniopsis 'Trinity' had the highest flowering percentage (> 90\%) when they were grown under a $9 \mathrm{~h}$ photoperiod at $20^{\circ} \mathrm{C}$ for 4-8 weeks and subsequently transferred to $14^{\circ} \mathrm{C}$ for 8 weeks (Lopez and Runkle, 2006). Ichihashi (1997) reported that flower initiation in mature pseudobulbs of Dendrobium occurred only when they were exposed to temperatures below $20^{\circ} \mathrm{C}$. Epidendrum and Phalaenopsis required relatively or absolutely low temperatures for flower initiation (Chae, 2002).

Increasing DLI increases biomass accumulation, decreased time to flower, and improves final plant quality in some herbaceous plants. For example, increasing DLI increased flower number and size in Petunia $\times$ hybrida (Kaczperski et al., 1991) and Catharanthus roseus (Pietsch et al., 1995). Days to flowering of Cyclamen persicum (Oh et al., 2009) decreased from 133 to 75 as DLI increased from 1.4 to $17.3 \mathrm{~mol} \cdot \mathrm{m}^{-2} \cdot \mathrm{s}^{-1}$. In the present study, shade condition decreased greenhouse PPF and DLI by approximately $48 \%$ compared to the mist condition during the daytime. The earlier flowering and flower induction under the mist condition could also be explained by the higher DLI.

Our data showed that NI promoted vegetative growth under both mist and shade treatments during the early growth stages, but no flowering occurred within 2 years when the plants were grown under NI and shade conditions. Temperature and DLI are factors for flowering of Cymbidium, but it cannot be determined if the promotion of flowering was from temperature, DLI or both in this study. Additional research in growth chambers with two light levels combined with two temperature range is needed to confirm whether the flower induction that occurred under the mist condition was because of cooler temperatures, higher DLI or both. However, the results of this study could be used to help commercial operations and improve efficiency of Cymbidium orchid production in a greenhouse. Under the NI condition in a greenhouse, mist system during the summer season could be a more effective cooling method for Cymbidium cultivation, than shade system or moving plants from lowto high-elevation areas.

\section{Literature Cited}

An, H.R., Y.J. Kim, and K.S. Kim. 2012. Flower initiation and development in Cymbidium by night interruption with potassium and nitrogen. Hort. Environ. Biotechnol. 53:204-211.

Arbel, A., O. Yekutieli, and M. Barak. 1999. Performance of a fog system for cooling greenhouse. J. Agr. Eng. Res. 72:129-136.

Bhattacharjee, S.K. 1979. Photoperiodism effects on growth and flowering in some species of orchids. Sci. Cult. 45:293-295.

Blanchard, M.G. and E.S. Runkle. 2010. Intermittent light from a rotating high-pressure sodium lamp promotes flowering of long-day plants. HortScience 45:236-241.

Cerdan, P.D. and J. Chory. 2003. Regulation of flowering time by light quality. Nature 423:881-885.

Chae, S.C. 2002. A scanning electron microscope observation of flower bud initiation and developmetn of Dendrobium nobile. Kor. J. Hort. Sci. Technol. 20:356-359.

Ichihashi, S. 1997. Orchid production and research in Japan, p. 171-212. In: J. Arditti and A.M. Pridgeon (eds.). Orchid biology: Reviews and perspectives VII. Kluwer Academic Publishers, Dordrecht, The Netherlands.

Kaczperski, M.P., W.H. Carlson, and M.G. Karlsson. 1991. Growth and development of Petunia $\times$ hybrida as a function of temperature and irradiance. J. Amer. Soc. Hort. Sci. 116:232-237.

Katsoulas, N., A. Baille, and C. Kittas. 2001. Effect of misting on transpiration and conductances of a greenhouse rose canopy. Agr. For. Meteorol. 106:233-247.

Kim, Y.J., H.J. Lee, and K.S. Kim. 2011. Night interruption promotes vegetative growth and flowering of Cymbidium. Scientia Hortic. 130:887-893.

Kim, Y.J., H.J. Lee, and K.S. Kim. 2013. Carbohydrate changes in Cymbidium 'Red Fire' in response to night interruption. Scientia Hortic. 162:82-89.

Klement, Z. 1990. Description and classification of disease symptoms, p. 134-143. In: Z. Klement, K. Rudolph, and D.C. Sands, (eds.). Methods in phytobacteriology. Akademiai Kiado, Budapest, Hungary.

Kosugi, K., M. Yokoi, N. Asai, and K. Matsuda. 1971. Flower bud formation in orchids: I. On the floral initiation and development in miniature cymbidiums. Tech. Bul. Fac. Hort. 
Chiba Univ. 19:23-27.

Kubota, S., J. Yamamoto, Y. Takazawa, H. Sakasai, K. Watanabe, K. Yoneda, and N. Matsui. 2005. Effects of light intensity and temperature on growth, flowering, and single-leaf $\mathrm{CO}_{2}$ assimilation in Odontioda orchid. J. Jpn. Soc. Hort. Sci. 74:330-336.

Lopez, R.G. and E.S. Runkle. 2004. The effect of temperature on leaf and flower development and flower longevity of Zygopetalum Redvale 'Fire Kiss' orchid. HortScience 39:1630-1634.

Lopez, R.G. and E.S. Runkle. 2005. Environmental physiology of growth and flowering of orchids. HortScience 40:1969-1973.

Lopez, R.G. and E.S. Runkle. 2006. Temperature and photoperiod regulate flowering of potted Miltoniopsis orchids. HortScience 41:593-597.

Ng, C.K.Y. and C.S. Hew. 2000. Orchid pseudobulbs - 'false' bulbs with a genuine importance in orchid growth and survival! Scientia Hortic. 83:165-172.

Oh, W., I.H. Cheon, K.S. Kim, and E.S. Runkle. 2009. Photosynthetic daily light integral influences flowering time and crop characteristics of Cyclamen persicum. HortScience 44:341-344.

Oh, W., Y.H. Rhie, J.H. Park, E.S. Runkle, and K.S. Kim. 2008. Flowering of cyclamen is accelerated by an increase in temperature, photoperiod, and daily light integral. J. Hort. Sci. Biotechnol. 83:559-562.

Perdigones, A., J.L. Garcia, A. Romero, A. Rodriguez, L. Luna, C. Raposo, and S. De La Plaza. 2008. Cooling strategies for greenhouses in summer: Control of fogging by pulse width modulation. Biosys. Eng. 99:573-586.

Pietsch, G.M., W.H. Carlson, R.D. Heins, and J.E. Faust. 1995. The effect of day and night temperature and irradiance on development of Catharanthus roseus (L.) 'Grape Cooler'. J. Amer. Soc. Hort. Sci. 120:877-881.

Pridgeon, A. 1992. The illustrated encyclopedia of orchids. Timber Press, Portland, OR, USA.

Romero-Aranda, R., T. Soria, and J. Cuartero. 2002. Greenhouse mist improves yield of tomato plants grown under saline conditions. J. Amer. Soc. Hort. Sci. 127:644-648.

Rotor, G.B. 1952. Daylength and temperature in relation to growth and flowering in orchids. Cornell Univ. Agr. Expt. Station Bull. 885:3-47.

Went, F.W. 1957. The experimental control of plant growth. Chronica Bot. 17:148-152.

Withner, C.L. 1974. Development in orchid physiology, p. 129-168. In: C.L. Withner (ed.). The orchids, scientific studies. WileyInterscience, New York, NY, USA.

Wright, P.J. and C.M. Triggs. 2009. Factors affecting bacterial soft rot of Zantedeschia tubers. New Zealand J. Crop Hort. Sci. 37:345-350.

Yamada, A., T. Tanigawa, T. Suyama, T. Matsuno, and T. Kunitake. 2008. Night break treatment using different light sources promotes or delays growth and flowering of Eustoma grandiflorum (Raf.) Shinn. J. Japan. Soc. Hort. Sci. 77:69-74. 